\title{
Corrigendum to "Probabilistic sensitivity analysis of two suspension bridges in Istanbul, Turkey to near- and far-fault ground motion" published in Nat. Hazards Earth Syst. Sci., 12, 459-473, 2012
}

\author{
Ö. Çavdar
}

Gümüşhane University, Department of Civil Engineering, 29000, Gümüşhane, Turkey

Correspondence to: Ö. Çavdar (ozlem_cavdar@hotmail.com)

In the paper "Probabilistic sensitivity analysis of two suspension bridges in Istanbul, Turkey to near- and far-fault ground motion (Çavdar, 2012) a number of citations were missing, in the text and in the list of references. Below we publishthe necessary corrections.

In section 1. Introduction:

The text "The suspension bridges, Fatih Sultan Mehmet and Bosporus bridges, located on Bosporus straits in Istanbul, a mega city of significant seismic hazard in Turkey. Istanbul has a population of approximately 15 million people, and is located astride the Bosporus, which divides it into European and Asian side." was missing a citation. The corrected text reads: "The suspension bridges, Fatih Sultan Mehmet and Bosporus bridges, located on Bosporus straits in Istanbul, a mega city of significant seismic hazard in Turkey. Istanbul has a population of approximately 15 million people, and is located astride the Bosporus, which divides it into European and Asian side (Memişoğlu Apaydın, 2010)".

The text "Suspension types of bridges are becoming more and more popular in the construction of long span bridges due to their many advantages, i.e. light in weight, efficient in load resistance, and of smaller cross sections. Suspension bridges which consist of main girders, towers and hanger are complicated structures." was missing a citation. The corrected text reads: "Suspension types of bridges are becoming more and more popular in the construction of long span bridges due to their many advantages, i.e. light in weight, efficient in load resistance, and of smaller cross sections. Suspension bridges which consist of main girders, towers and hanger are complicated structures (Çavdar et al., 2010)".

The text "The hangers are vertical and connect to the deck and cable with singly hinged bearing" was missing a citation. The corrected text reads: "The hangers are vertical and con- nect to the deck and cable with singly hinged bearing (Çavdar et al., 2011)".

The text "It produces high input energy on structures in the beginning of the earthquake" was missing a citation. The corrected text reads: "It produces high input energy on structures in the beginning of the earthquake (Bayraktar et al., 2009)".

The text "The ground motions with the velocity pulses recorded in the vicinity of an earthquake fault are quite different from the usual far-fault earthquake ground motions" was missing a citation. The corrected text reads: "The ground motions with the velocity pulses recorded in the vicinity of an earthquake fault are quite different from the usual far-fault earthquake ground motion (Akköse et al., 2010)".

The text "Comparison of the near-fault strong ground motion velocities with far-fault strong ground motions is shown in Fig. 1. These pulses are strongly influenced by the orientation of the fault, the direction of slip on the fault and the location of the recording station relative to the fault, which is termed as "directivity effect" due to the propagation of the rupture toward the recording site" was missing a citation. The corrected text reads: "Comparison of the near-fault strong ground motion velocities with far-fault strong ground motions is shown in Fig. 1. These pulses are strongly influenced by the orientation of the fault, the direction of slip on the fault and the location of the recording station relative to the fault, which is termed as "directivity effect" due to the propagation of the rupture toward the recording site (Bayraktar et al., 2009)".

The text "The velocity pulse duration in the near-fault ground motions is larger than $1.0 \mathrm{~s}$. In addition, the ratio of the peak ground velocity (PGV) to the peak ground acceleration (PGA) of the near-fault ground motions is larger than $0.1 \mathrm{~s}$. The ground motions having these characteristics expose the structure to high input energy in the beginning of 
the earthquake and cause large structural responses. Therefore, structural response to near-fault ground motions has received much attention in recent years. So far, dynamic response analyses of some structures subjected to near-fault ground motions have been performed. In these studies, it is seen that long period structures such as frame buildings and bridges experience a higher dynamic response when they are subjected to near-fault ground motion" was missing a citation. The corrected text reads: "The velocity pulse duration in the near-fault ground motions is larger than $1.0 \mathrm{~s}$. In addition, the ratio of the peak ground velocity (PGV) to the peak ground acceleration (PGA) of the near-fault ground motions is larger than $0.1 \mathrm{~s}$. The ground motions having these characteristics expose the structure to high input energy in the beginning of the earthquake and cause large structural responses. Therefore, structural response to near-fault ground motions has received much attention in recent years. So far, dynamic response analyses of some structures subjected to near-fault ground motions have been performed. In these studies, it is seen that long period structures such as frame buildings and bridges experience a higher dynamic response when they are subjected to near-fault ground motion (Akköse et al., 2010)".

The text "In these studies, it is seen that long period structures such as frame buildings and bridges experience a higher dynamic response when they are subjected to near-fault ground motion" was missing a citation. The corrected text reads: "In these studies, it is seen that long period structures such as frame buildings and bridges experience a higher dynamic response when they are subjected to near-fault ground motion (Akköse et al., 2010)".

The text "It can be clearly seen from these studies that the importance of near-fault ground motion effect on the response of the structures have been highlighted" was missing a citation. The corrected text reads: "It can be clearly seen from these studies that the importance of near-fault ground motion effect on the response of the structures have been highlighted (Bayraktar et al., 2009)".

The text "These studies were based on the assumption of complete determinacy of structural parameters. This is usually referred to as deterministic analysis. In reality, however, there are uncertainties in design variables. These uncertainties include geometric properties, material mechanical properties, load magnitude and distribution, etc. Therefore, deterministic analysis cannot provide complete information regarding dynamic responses of long-span bridges with cables" was missing a citation. The corrected text reads: "These studies were based on the assumption of complete determinacy of structural parameters. This is usually referred to as deterministic analysis. In reality, however, there are uncertainties in design variables. These uncertainties include geometric properties, material mechanical properties, load magnitude and distribution, etc. Therefore, deterministic analysis cannot provide complete information regarding dynamic responses of long-span bridges with cables (Çavdar et al., 2010)".
The text "For comparison, earthquake ground motions recorded at the same site from Kocaeli earthquake, the epicenter of which is far away from the site, are employed as the far-fault ground motions, to illustrate the difference between the near-fault and far-fault earthquake characteristics"was missing a citation. The correct text reads: "For comparison, earthquake ground motions recorded at the same site from Kocaeli earthquake, the epicenter of which is far away from the site, are employed as the far-fault ground motions, to illustrate the difference between the near-fault and far-fault earthquake characteristics (Bayraktar et al., 2009)".

The text "This work carries a great importance due to the fact that it includes the probabilistic dynamics sensitivity analysis of Bosporus and Fatih Sultan Mehmet Bridges and earthquake performance under the action of Kocaeli earthquake for the both bridges at the same time and in the same work" was missing a citation. The correct text reads: "This work carries a great importance due to the fact that it includes the probabilistic dynamics sensitivity analysis of Bosporus and Fatih Sultan Mehmet Bridges and earthquake performance under the action of Kocaeli earthquake for the both bridges at the same time and in the same work (Memişoğlu Apaydın, 2010)".

The text "The record at the Yarimca station (Fig. 2) of the Kocaeli earthquake is selected torepresent the characteristics of near-fault ground motion"was missing a citation. The correct text reads: "The record at the Yarimca station (Fig. 2) of the Kocaeli earthquake is selected to represent the characteristics of near-fault ground motion (Akköse, 2010)".

The text "Some important parameters, such as the ratio of PGV to PGA, normalized spectral velocity and the energy of the ground motion, are evaluated in the present study and to discuss the feature of bridges to NF and FF ground motions, where the normalized spectral velocity means the response spectral velocity obtained by scaling the PGA of the input ground motion" was missing a citation. The correct text reads: "Some important parameters, such as the ratio of PGV to PGA, normalized spectral velocity and the energy of the ground motion, are evaluated in the present study and to discuss the feature of bridges to NF and FF ground motions, where the normalized spectral velocity means the response spectral velocity obtained by scaling the PGA of the input ground motion (Liao et al., 2004)".

The text "The Kocaeli (1999) earthquake was recorded with the magnitude of 7.4 and this magnitude is the same for both records considered in this study. The distance of the recording site from the source is ranged from 2.6 to $17 \mathrm{~km}$. A scatter plot of the magnitude-distance pair for the records of strong ground motions is shown in Fig. 5. The record characterizing near-fault ground motion is obtained from the distance less than $10 \mathrm{~km}$ to epicenter and the other record characterizing far-fault ground motion is obtained from the distance more than $10 \mathrm{~km}$ to epicenter." was missing a citation. The correct text reads: "The Kocaeli (1999) earthquake was recorded with the magnitude of 7.4 and this magnitude is the 
same for both records considered in this study. The distance of the recording site from the source is ranged from 2.6 to $17 \mathrm{~km}$. A scatter plot of the magnitude-distance pair for the records of strong ground motions is shown in Fig. 5. The record characterizing near-fault ground motion is obtained from the distance less than $10 \mathrm{~km}$ to epicenter and the other record characterizing far-fault ground motion is obtained from the distance more than $10 \mathrm{~km}$ to epicenter (Bayraktar et al., 2009)"

In sub-section 4.1 Probabilistic sensitivity earthquake response of Bosporus Suspension Bridge:

The text "Bosporus suspension bridge, commissioned in 1973, joins the European and Asian Continents through Ortakoy and Beylerbeyi districts of Istanbul. It is a gravityanchored suspension bridge with steel pylons and inclined hangers." was missing a citation. The correct text reads: "Bosporus suspension bridge, commissioned in 1973, joins the European and Asian Continents through Ortakoy and Beylerbeyi districts of Istanbul. It is a gravity-anchored suspension bridge with steel pylons and inclined hangers (Memişoğlu Apaydın, 2010)".

The text "The horizontal distance between the cables is $28 \mathrm{~m}$ and the roadway is $21 \mathrm{~m}$ wide, accommodating three lanes each way. The roadway at the mid-span of the bridge is approximately $64 \mathrm{~m}$ above the sea level" was missing a citation. The correct text reads: "The horizontal distance between the cables is $28 \mathrm{~m}$ and the roadway is $21 \mathrm{~m}$ wide, accommodating three lanes each way. The roadway at the mid-span of the bridge is approximately $64 \mathrm{~m}$ above the sea level (Adanur et al., 2006)".

The text "This model has three degrees of freedom at each nodal point, namely, two translational degrees of freedom in vertical and longitudinal axes and one rotational degree of freedom in lateral axis" was missing a citation. The correct text reads: "This model has three degrees of freedom at each nodal point, namely, two translational degrees of freedom in vertical and longitudinal axes and one rotational degree of freedom in lateral axis (Çavdar et al., 2010)".

The text "Elastic module from material properties is chosen as random variable for the suspension bridge. The other variables are considered as deterministic" was missing a citation. The correct text reads: "Elastic module from material properties is chosen as random variable for the suspension bridge. The other variables are considered as deterministic (Çavdar et al., 2011)".

The text "NF ground motion are greater than those for FF ground motion although the peak ground acceleration of NF and FF records is the same" was missing a citation. The correct text reads: "NF ground motion are greater than those for FF ground motion although the peak ground acceleration of NF and FF records is the same (Akköse et al., 2010)".

In Sect. 5, Conclusions:

The text"According to this study, the earthquake record of the NF and FF ground motion, forming of the combination of numerous waves, has remarkable effect on the probabilis- tic sensitivity earthquake response of the" was missing a citation. The correct text reads: "According to this study, the earthquake record of the NF and FF ground motion, forming of the combination of numerous waves, has remarkable effect on the probabilisticsensitivity earthquake response of the (Bayraktar et al., 2009)".

\section{References}

Adanur, S., Soyluk, K., Dumanoğlu, A., and Bayraktar, A.: Asynchronous and Antisynchronous Effects of Ground Motion on the Stochastic Response of Suspension Bridges, Springer Proceedings in Physics, 2006.

Akköşe, M. and Şimşek, E.: Non-linear seismic response of concrete gravity dams to near-fault ground motions including damwater-sediment-foundation interaction, Appl. Math. Model., 34, 3685-3700, doi:10.1016/j.apm.2010.03.019, 2010.

Bayraktar, A., Altunışık, A. C., Sevim, B., Kartal, M. E., Türker, T., and Bilici, Y.: Near-fault ground motion effects on the nonlinear responseof dam-reservoir-foundation systems, Struct. Eng. Mech., 58, 4, 655-673, doi:10.1007/s11071-009-9508-x, 2009.

Çavdar, Ö., Bayraktar, A., Adanur, S., and Başağa, H. B.: Stohastic finite element analysis of long-span bridges with CFRP cables under earthquake ground motions, Sadhana Academcy of Sciences, 35, 341-354, 2010.

Çavdar, Ö., Bayraktar, A., Adanur, S., and Çavdar, A.: Effect of random material and geometrical properties on structural safety steel-concrete composite systems, International Journal for $\mathrm{Nu}$ merical Methods in Biomedical Engineering, 27, 1473-1492, 2011, doi:10.1002/cnm.1377.

Çavdar, Ö., Bayraktar, A., and Adanur, S.: Stochastic finite element analysis of a cable-stayed bridge system with varyingmaterial properties, Probabilistic Eng. Mech., 25, 279-289, 2010.

Liao, W. I., Loh, C. H., and Lee, B. H.: Comparison of dynamic response of isolated and non-isolated continuous girder bridges subjected to near-fault ground motions, Eng. Struct., 26, 14, 2173-2183, 2004, doi:10.1016/j.engstruct.2004.07.016.

Memişoğlu Apaydın, N.: Earthquake performance assessment and retrofit investigationsof two suspension bridges in Istanbul, Soil Dynam. Earthquake Eng., 30, 702-710, doi:10.1016/j.soildyn.2010.02.011, 2010. 